\title{
DOES THE QUALITY OF GOVERNANCE MATTER FOR EQUITY MARKET RISK? EVIDENCE FROM EMERGING AND DEVELOPED EQUITY MARKETS
}

\author{
Soo-Wah LOW ${ }^{1}$, Lain-Tze TEE ${ }^{2}$, Si-Roei KEW ${ }^{3}$ \\ ${ }^{1}$ Graduate School of Business (UKM-GSB), Universiti Kebangsaan Malaysia, \\ 43600 UKM Bangi, Selangor, Malaysia \\ ${ }^{2,3}$ School of Management, Faculty of Economics and Management, \\ Universiti Kebangsaan Malaysia, 43600 UKM Bangi, Selangor, Malaysia \\ E-mails: ${ }^{1}$ swlow@ukm.edu.my; soowah.low@gmail.com (corresponding author)
}

Received 23 February 2012; accepted 06 August 2012

\begin{abstract}
This paper examines the relation between country-level governance and crosscountry differences in equity market risk by employing panel data regressions. For emerging markets, we find consistent evidence that governance quality of various dimensions is negatively related to equity market risk. On the contrary, for developed markets, the results show that there is generally little or no relation between governance quality and equity market risk. The results provide practical implication to policy makers of emerging markets by highlighting the relevant governance dimensions that constitute important drivers of stock market risk. The findings have academic implication in the context of equilibrium pricing of stock market in emerging market.
\end{abstract}

Keywords: country-level governance, equity market risk, governance quality, stock market, governance risks, standard deviation of equity return, semi-deviation of equity return.

JEL Classification: G15, G30, G38.

\section{Introduction}

The emergence of globalization has caused country-level governance to become one of the most important policy issues within the realm of finance. The occurrence of international financial crisis has strengthened the belief that governance quality plays significant role in influencing the financial system. It is widely believed that poor governance quality hinders economic growth and financial development. In other words, good governance and institutions are certainly prerequisites for the development of financial markets. As defined by Kaufmann et al. (2010: 4), governance is "...the traditions and institutions by which authority in a country is exercised. This includes a process by which governments are selected, monitored, and replaced; the capacity of the government to effectively formulate and implement sound policies; and the respect of citizens and the state for the institutions that govern economic and social interactions among them". 
Prior research has established that important interplay exists between governance mechanism at firm level and country-level governance framework. An assessment of corporate governance at firm level is an ideal starting point for regulators to have deep insights about the effect of country-level governance quality on stock market risk since both the governance mechanisms interact with each other and neither one is able to function properly on its own. Collectively, the available research find that the quality of country-level governance has profound impacts on corporate policies and the operation of financial markets through its influences on the availability of external financing, cost of capital, corporate valuations, stock market performance, and investment quality (Hail, Leuz 2006; Daouk et al. 2006; Hooper et al. 2009; Yartey 2010; Giannetti, Koskinen 2010; Chiou et al. 2010; Low et al. 2011).

Studies that examine the relation between governance quality and equity returns have reached varied conclusions and attribute the findings to heightened investors' concerns on investment risk. Hooper et al. (2009) find that good governance quality increases the demand on equity and thus maximizes stock returns through the reduction in transaction and agency costs. On the contrary, Low et al. (2011) provide evidence that on average, countries with weak governance framework characterized by political instability, poor investor protection, ineffective government, poor regulatory quality, and lack of control for corruption, exhibit higher equity returns than countries with strong governance settings.

In the present study, we examine the influence of a country's governance quality on the variation in equity market risk in emerging and developed markets over the period from January 2002 to December 2009 using panel data regression. We employ the six governance dimensions of the World Bank's Worldwide Governance Indicators (WGI) to measure the quality of a country's governance framework. The findings of this study shed light on the relevant aspects of governance that constitute key drivers of equity market risk. This study is organized as follows. Section 1 reviews the existing literature and Section 2 presents the data and methodology. Findings are discussed in Section 3 and final section concludes the study.

\section{Literature review}

Prior studies have established that cross-country differences in governance framework have important implications. La Porta et al. $(1997,1998)$ provide evidence that countries with better legal rules and efficient enforcement of laws have easier access to external funds in the financial markets and thus investors are more willing to invest in such countries than in those with poor investor protections. Similar insights are found in studies by Claessens et al. (2000), Berkowitz et al. (2003), Beck et al. (2003), Klapper and Love (2004), Lombardo and Pagano (2006), among others. The findings of Dumludag (2009) suggest that institutional governance is crucial in attracting foreign direct investment (FDI) into Turkey. Institutional-related factors identified as barriers to FDI inflows are ineffective government, weak regulatory structure, poor enforcement in the rule of law and pervasiveness of corruption. There is a growing body of empiri- 
cal evidence indicating that understanding the impact of country-level governance on stock market risk is vital for determining cost of capital and facilitating asset allocation decisions. Hail and Leuz (2006) show that countries with effective securities regulations and strong supporting legal institutions have lower levels of cost of equity capital than those with inefficient regulations and legal systems. Chen et al. (2009) find that firmlevel governance is negatively related to cost of equity capital and the effect is more pronounced in poor investor protection countries. Daouk et al. (2006) find that effective insider trading laws enforcement, transparent accounting standards and relaxation of short selling restrictions are associated with good governance quality which reduces cost of capital, increases market liquidity and price efficiency all of which decreases investment risk.

The nexus between governance and stock market is appealing given the mixed findings on the relation between governance and stock market returns most of which are attributed to heightened concerns on investment risk. Giannetti and Koskinen (2010) argue that countries with weak investor protection have lower returns due to lesser demand for the stocks. The findings of Gompers et al. (2003) indicate that firms with weak governance structures are associated with high agency costs leading to low stock valuations and returns. Hooper et al. (2009) show that governance quality measured by political stability is key governance dimension that positively affects international equity returns. On the contrary, Low et al. (2011) find evidence of significant negative link between governance quality and stock market returns. The findings indicate that poor governance quality increases stock market uncertainty and therefore accords higher equity returns to offset the higher risk borne by investors.

Chiou et al. (2010) find that effective legal systems, low corruptions, strong investor protection rights, stable political environment reduce stock market risk. Aggarwal et al. (1999) find that high political risk and poor quality of institutions lead to greater stock market volatility and conclude that country-specific events are the key factors that increase stock market volatility in emerging countries. Such finding is in line with Harvey's (1995) findings that stock markets in emerging countries have higher return volatility and larger risk premiums. Bialkowski et al. (2008) report that variance of stock market return increases considerably around national elections. Franck and Krausz (2009) find that unstable domestic political environments imply higher risk in stock markets. Eldor and Melnick (2004) show that terror attacks have lasting negative impacts on equity market but not on currency market in Israel. Kim and Mei (2001) find that political risk has significant influence on stock market volatility. Chau et al. (2014) report that political chaos fuels stock market volatility in Middle East and North African countries. Charles and Darne (2014) reveal that wars, national elections, and terrorist attacks contribute to large volatility shocks in the United States stock market.

In this study, we expand the literature by examining whether a country's governance quality plays important role in explaining international differences in equity market risk. Our study is most closely related to Hooper et al.'s (2009) who find that stock markets in better governed countries have higher equity returns and lower risk levels. 
They find that the governance quality as measured by voice and accountability, political stability, government effectiveness, regulatory quality, rule of law, and control of corruption are all significant and negatively associated with equity market risk. However, the investigation of stock market risk represents only a small section of the study and it did not examine the separate impacts of emerging versus developed countries. In this study, we enhance the understanding of the key governance dimensions that drive stock market risk using a longer sample period and separating the sample into emerging and developed market countries.

\section{Data and methodology}

The study sample consists of 21 emerging markets and 24 developed markets with complete relevant data for the period from January 2002 to December 2009. The data on Morgan Stanley Capital International (MSCI) country indices which are value-weighted national indices with dividend reinvestments are used to calculate international equity market risk as measured by standard deviation of equity return and semi-deviation of equity return. The proxies for country-level governance quality were sourced from the World Bank's Worldwide Governance Indicators (WGI), available at www.govindicators.org. The description of governance variables used in this study is summarized in Appendix A. The data on MSCI country index series, MSCI world stock market index, and US one-month T-bill were sourced from Datastream. We include four other global risk factors known to influence international equity market risk as employed by Low et al. (2011), Hooper et al. (2009), Hail and Leuz (2006), Mateus (2004), Ferson and Harvey (1993), and Dumas and Solnik (1995). The global risk factors are G7 inflation rate, crude oil spot price changes, G7 industrial production changes, and G10 exchange rate index changes. The data on inflation, crude oil, and industrial production were sourced from Datastream while the data on foreign exchange were retrieved from the Federal Reserve Bank of St. Louis.

We employ two measures of stock market risk as dependent variables, i.e., standard deviation of equity return and semi-deviation of equity return as discussed in Estrada (2007) and given by Equation (1) and (2) respectively:

$$
\begin{gathered}
\sigma_{i t}=\sqrt{E\left[\left(R_{i t}-\mu_{i t}\right)^{2}\right]}, \\
\Sigma_{i t}=\sqrt{E\left\{\min \left[\left(R_{i t}-\mu_{i t}\right), 0\right]^{2}\right\}},
\end{gathered}
$$

where $R_{i t}$ and ${ }_{i t}$ are returns and mean returns of each country $i$ and for each year $t$ respectively. We first estimate the world beta for each country and for each year as shown in Equation (3):

$$
R_{i t}-R_{t}^{R F}=\theta_{i t}+\beta_{i t}^{W O R L D}\left(R_{t}^{W}-R_{t}^{R F}\right)+\varepsilon_{i t}, i=1, \ldots, N ; t=1, \ldots, T,
$$

where $R_{i t}$ is the return of country $i$ 's MSCI equity index for week $t ; R^{R F}$ is the US 1-month t-bill rate; $R^{W}$ is the MSCI USD value-weighted world index for week $t$; $\beta^{\text {WORLD }}{ }_{i t}$ is the world beta for country $i$ and for time $t$; and $\theta_{i t}$ and $\varepsilon_{i t}$ are the intercept 
and error term of country $i$ in period $t$. We regress equity market risk measure on governance indicators, world beta, and other global risk factors employing panel data regression model as shown in Equation (4):

$$
\begin{aligned}
& \frac{\gamma_{i t}}{\sigma_{G_{i t}}}=\beta_{0}+\beta_{1}\left(\frac{G_{i t}}{\sigma_{G_{i t}}}\right)+\beta_{2}\left(\frac{\beta^{W O R L D} D_{i t}}{\sigma_{G_{i t}}}\right)+\beta_{3}\left(\frac{C P I_{t}}{\sigma_{G_{i t}}}\right)+\beta_{4}\left(\frac{F O R E X_{t}}{\sigma_{G_{i t}}}\right)+ \\
& \beta_{5}\left(\frac{O I L_{t}}{\sigma_{G_{i t}}}\right)+\beta_{6}\left(\frac{I P R O D_{t}}{\sigma_{G_{i t}}}\right)+\mu_{i}+e_{i t}, i=1, \ldots N ; t=1, \ldots, T,
\end{aligned}
$$

where $\gamma_{i t}$ is the equity market risk of country $i$ for year $t$. The variable $\beta^{W O R L D}$ it is the beta coefficient estimated from Equation (3) for country $i$ and year $t$. The variables $C P I, F O R E X, O I L$, and IPROD are global risk factors and they represent $\mathrm{G} 7$ inflation rate, G10 exchange rate index changes, crude oil spot price changes, and G7 industrial production changes respectively. The variable $G_{i t}$ is governance score for each country in a given year and following the adjustment procedure of Hooper et al. (2009), we divide each governance indicator by its respective standard error, $\sigma_{G i t}$. Separate regression model for each of the governance indicator is employed to avoid the potential problem of multicollinearity problem due to high correlations among the governance indicators as reported in Appendix B. The vector $\beta$ is the coefficient to be estimated; $e_{i t}$ is the idiosyncratic error term; $\mu_{\mathrm{i}}$ is the unobserved heterogeneity for country $i$, representing fixed effect if it is a fixed unknown parameter or random effect if it is a random variable. We perform Hausman test to determine the appropriateness of the fixed effect and random effect model.

\section{Empirical findings and discussion}

Table 1 provides summary statistics of equity returns and equity market risk by country for the period from January 2002 to December 2009. It is observed that emerging equity markets have higher average stock returns, are more volatile and generally have more risk on the downside than developed markets. On average, the standard deviation of equity returns for emerging markets is 3.56 percent as compared to the 2.84 percent for developed markets. Similarly, emerging equity markets also exhibit a slightly higher level of semi-deviation of equity return than the developed market.

Table 2 reports summary statistics for variables employed in the study. The average overall governance index for emerging markets is 0.0877 and 1.3861 for developed markets. The quality of governance as measured by Political Stability and Absence of Violence (G2) has the lowest governance score in both emerging and developed markets. Lowest average score on this indicator among the six governance indicators implies that political dimension deserves urgent policy attention of policy makers in both emerging and developed markets. In emerging equity markets, Regulatory Quality (G4) has the highest average governance score of 0.3365 and the corresponding average score for developed markets is 1.4615 . In developed markets, the indicator Control of Corruption (G6) has the highest average score of 1.6606 suggesting that corruption activities seem to be minimal in developed countries. 
Table 1. Summary statistics of equity returns and risk by country from January 2002 - December 2009

\begin{tabular}{|c|c|c|c|c|}
\hline Market and country & Mean return & Total risk & Downside risk & Skewness \\
\hline \multicolumn{5}{|c|}{ Panel A: Emerging markets } \\
\hline Brazil & 0.0045 & 0.0388 & 0.0279 & -0.2535 \\
\hline Chile & 0.0028 & 0.0249 & 0.0177 & -0.6647 \\
\hline China & 0.0041 & 0.0403 & 0.0283 & -0.1226 \\
\hline Colombia & 0.0067 & 0.0333 & 0.0239 & -0.6354 \\
\hline Czech Republic & 0.0038 & 0.0336 & 0.0245 & -0.5677 \\
\hline Egypt & 0.0071 & 0.0412 & 0.0295 & -0.5627 \\
\hline Hungary & 0.0030 & 0.0388 & 0.0279 & -0.7200 \\
\hline India & 0.0046 & 0.0343 & 0.0251 & -0.4410 \\
\hline Indonesia & 0.0059 & 0.0411 & 0.0285 & -0.2931 \\
\hline Korea & 0.0030 & 0.0372 & 0.0264 & -0.0508 \\
\hline Malaysia & 0.0017 & 0.0199 & 0.0139 & -0.4402 \\
\hline Mexico & 0.0040 & 0.0315 & 0.0227 & -0.1971 \\
\hline Morocco & 0.0020 & 0.0242 & 0.0173 & -0.2818 \\
\hline Peru & 0.0060 & 0.0420 & 0.0301 & -0.2379 \\
\hline Philippines & 0.0023 & 0.0335 & 0.0232 & -0.2525 \\
\hline Poland & 0.0021 & 0.0347 & 0.0240 & 0.0275 \\
\hline Russia & 0.0044 & 0.0531 & 0.0370 & 1.4214 \\
\hline South Africa & 0.0024 & 0.0289 & 0.0203 & 0.3185 \\
\hline Taiwan & 0.0009 & 0.0323 & 0.0230 & 0.0135 \\
\hline Thailand & 0.0032 & 0.0356 & 0.0255 & -0.6958 \\
\hline Turkey & 0.0040 & 0.0474 & 0.0325 & 0.3972 \\
\hline \multicolumn{5}{|c|}{ Panel B: Developed markets } \\
\hline Australia & 0.0011 & 0.0205 & 0.0150 & -0.8289 \\
\hline Austria & 0.0014 & 0.0323 & 0.0240 & -1.5537 \\
\hline Belgium & -0.0006 & 0.0296 & 0.0220 & -1.3207 \\
\hline Canada & 0.0015 & 0.0237 & 0.0174 & -0.5655 \\
\hline Denmark & 0.0013 & 0.0274 & 0.0201 & -1.0963 \\
\hline Finland & -0.0007 & 0.0403 & 0.0285 & -0.2177 \\
\hline France & 0.0001 & 0.0283 & 0.0205 & -0.8928 \\
\hline Germany & 0.0004 & 0.0320 & 0.0228 & -0.3815 \\
\hline Greece & 0.0002 & 0.0335 & 0.0236 & -0.2931 \\
\hline
\end{tabular}


End of Table 1

\begin{tabular}{lcccc}
\hline \multicolumn{1}{c}{ Market and country } & Mean return & Total risk & Downside risk & Skewness \\
\hline Hong Kong & 0.0017 & 0.0286 & 0.0197 & -0.1775 \\
\hline Ireland & -0.0021 & 0.0358 & 0.0264 & -1.2026 \\
\hline Israel & 0.0022 & 0.0280 & 0.0202 & -0.4405 \\
\hline Italy & -0.0003 & 0.0268 & 0.0203 & -1.5209 \\
\hline Japan & 0.0001 & 0.0286 & 0.0206 & -0.8444 \\
\hline Netherlands & -0.0001 & 0.0303 & 0.0225 & -1.3863 \\
\hline New Zealand & 0.0000 & 0.0190 & 0.0138 & -0.7710 \\
\hline Norway & 0.0020 & 0.0336 & 0.0251 & -0.8296 \\
\hline Portugal & 0.0001 & 0.0226 & 0.0162 & -1.1206 \\
\hline Singapore & 0.0017 & 0.0278 & 0.0192 & 0.0039 \\
\hline Spain & 0.0013 & 0.0279 & 0.0206 & -1.1075 \\
\hline Sweden & 0.0010 & 0.0316 & 0.0226 & -0.5079 \\
\hline Switzerland & 0.0005 & 0.0254 & 0.0183 & -0.9447 \\
\hline UK & 0.0004 & 0.0239 & 0.0173 & -0.9105 \\
\hline USA & 0.0003 & 0.0241 & 0.0171 & -0.5463 \\
\hline \hline Mean of emerging markets & 0.0037 & 0.0356 & 0.0252 & -0.2018 \\
\hline Mean of developed markets & 0.0006 & 0.0284 & 0.0206 & -0.8107 \\
\hline
\end{tabular}

Table 3 and Table 4 report findings of the relationships between governance quality and equity market risk using two equity market risk measures as dependent variables, i.e., standard deviation and semi-deviation of equity return respectively. In all regression models in Tables 3 and 4, the reported $t$-statistics are corrected for country-specific heteroskedasticity. The Hausman test statistics are not significant in all regression models, suggesting that the application of random effect model is more appropriate than fixed effect model. In addition, the Breusch-Pagan Lagrange Multiplier (LM) test also confirms that the random effect model is a preferred model. Hence, random effect models are applied in all regression specifications. In Table 3, the dependent variable employed the standard deviation of a country's MSCI returns. For emerging equity markets, the results show that country-level governance are important drivers of equity market risk. The six regression models have R-squared values that range from 0.53 to 0.70 and the results show that the quality of governance as measured by Voice and Accountability (G1), Political Stability and Absence of Violence (G2), Government Effectiveness (G3), Regulatory Quality (G4), Rule of Law (G5), and Control of Corruption (G6) are all negatively and significantly related to total equity market risk after controlling for exposures to common world factors. Our findings suggest that country-level governance risks are important components of equity market risk in emerging markets. For developed equity markets, interestingly, in all regression models 1 through 6, we find that none of the six governance indicators is significant in explaining the cross-sectional variation in equity market risk. 
Table 2. Descriptive statistics from January 2002 through December 2009

\begin{tabular}{|c|c|c|c|c|c|c|c|c|c|c|}
\hline \multirow[b]{2}{*}{ Variables } & \multicolumn{5}{|c|}{ Panel A: Emerging markets } & \multicolumn{5}{|c|}{ Panel B: Developed markets } \\
\hline & 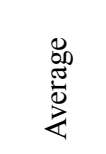 & 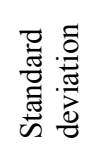 & 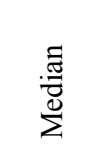 & 主 & $\underset{\sum}{\stackrel{\Xi}{\Xi}}$ & 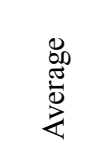 & 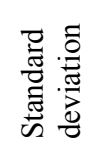 & 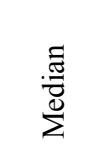 & $\stackrel{\Xi}{\Xi}$ & 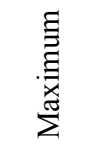 \\
\hline \multicolumn{11}{|c|}{ Stock risk measures } \\
\hline Total risk & 0.0356 & 0.0141 & 0.0326 & 0.0121 & 0.1165 & 0.0284 & 0.0135 & 0.0250 & 0.0104 & 0.0804 \\
\hline Downside risk & 0.0252 & 0.0095 & 0.0236 & 0.0083 & 0.0672 & 0.0206 & 0.0099 & 0.0181 & 0.0077 & 0.0588 \\
\hline \multicolumn{11}{|c|}{ Governance indicators } \\
\hline $\begin{array}{l}\text { Voice and } \\
\text { accountability } \\
\text { (G1) }\end{array}$ & 0.0939 & 0.7466 & 0.0746 & -1.7187 & 1.2185 & 1.2425 & 0.4309 & 1.3810 & -0.4552 & 1.8267 \\
\hline $\begin{array}{l}\text { Political } \\
\text { stability and } \\
\text { absence of } \\
\text { violence (G2) }\end{array}$ & -0.2640 & 0.7844 & -0.3574 & -2.1949 & 1.1240 & 0.8432 & 0.5463 & 0.9987 & -1.4505 & 1.5769 \\
\hline $\begin{array}{l}\text { Government } \\
\text { effectiveness } \\
\text { (G3) }\end{array}$ & 0.3038 & 0.5410 & 0.1532 & -0.6038 & 1.3088 & 1.6091 & 0.4171 & 1.7115 & 0.3329 & 2.2672 \\
\hline $\begin{array}{l}\text { Regulatory } \\
\text { quality (G4) }\end{array}$ & 0.3365 & 0.5657 & 0.2752 & -0.6556 & 1.5871 & 1.4615 & 0.3024 & 1.5406 & 0.5368 & 1.9922 \\
\hline $\begin{array}{l}\text { Rule of law } \\
\text { (G5) }\end{array}$ & 0.0688 & 0.6347 & 0.0169 & -1.0006 & 1.2950 & 1.4997 & 0.3755 & 1.6343 & 0.3134 & 1.9640 \\
\hline $\begin{array}{l}\text { Control of } \\
\text { corruption } \\
\text { (G6) }\end{array}$ & -0.0128 & 0.5627 & -0.1403 & -1.1219 & 1.5632 & 1.6606 & 0.5584 & 1.8274 & 0.0548 & 2.4666 \\
\hline $\begin{array}{l}\text { Overall } \\
\text { governance }\end{array}$ & 0.0877 & 0.5793 & -0.0681 & -0.9199 & 1.2644 & 1.3861 & 0.3548 & 1.4635 & 0.4895 & 1.9006 \\
\hline \multicolumn{11}{|c|}{ Global risk factors } \\
\hline$\beta^{\mathrm{WORLD}}$ & 0.8389 & 0.5085 & 0.8360 & -0.2261 & 2.0586 & 0.9266 & 0.3137 & 0.9553 & 0.0286 & 1.8424 \\
\hline CPI & 0.0188 & 0.0091 & 0.0210 & -0.0010 & 0.0318 & 0.0188 & 0.0091 & 0.0210 & -0.0010 & 0.0318 \\
\hline FOREX & -0.0411 & 0.0491 & -0.0330 & -0.1308 & 0.0429 & -0.0411 & 0.0491 & -0.0330 & -0.1308 & 0.0429 \\
\hline OIL & 1.7288 & 24.4034 & 4.1500 & -55.2400 & 34.8500 & 1.7288 & 24.3943 & 4.1500 & -55.2400 & 34.8500 \\
\hline IPROD & -0.0084 & 0.0546 & 0.0158 & -0.1432 & 0.0279 & -0.0084 & 0.0546 & 0.0158 & -0.1432 & 0.0279 \\
\hline
\end{tabular}

Notes: The equity market risk measures are: total risk, calculated as the standard deviation in equity returns; downside risk or semi-deviation is the downside standard deviation in equity returns. G1 through G6 are the six governance indicators measuring various dimensions of country-level governance. $\beta^{\text {WORLD }}$ is the world beta coefficient and it captures sensitivity of country $i$ 's equity return to world market movement. The variables CPI, FOREX, OIL, and IPROD are other global risk factors as represented by inflation rate, foreign exchange rate, crude oil spot price changes, and industrial production growth respectively. 
Table 3. Panel regression of equity market risk on governance variables and global risk factors over the period January 2002 - December 2009

\begin{tabular}{|c|c|c|c|c|c|c|}
\hline & ( 1 ) & (2) & ( 3 ) & $(4)$ & $(5)$ & ( 6 ) \\
\hline \multicolumn{7}{|c|}{ Panel A: Emerging markets } \\
\hline $\mathrm{G} i$ & $\begin{array}{c}-0.0054 \\
(-2.69)^{* *}\end{array}$ & $\begin{array}{l}-0.0031 \\
(-2.09)^{*}\end{array}$ & $\begin{array}{l}-0.0079 \\
(-4.26)^{* *}\end{array}$ & $\begin{array}{l}-0.0071 \\
(-2.81)^{* *}\end{array}$ & $\begin{array}{c}-0.0060 \\
(-3.24)^{* *}\end{array}$ & $\begin{array}{c}-0.0084 \\
(-3.35)^{* *}\end{array}$ \\
\hline$\beta^{\text {WORLD }}$ & $\begin{array}{c}0.0139 \\
(4.62)^{* *}\end{array}$ & $\begin{array}{c}0.0101 \\
(3.55)^{* *}\end{array}$ & $\begin{array}{c}0.0078 \\
(2.92)^{* *}\end{array}$ & $\begin{array}{c}0.0100 \\
(3.72)^{* *}\end{array}$ & $\begin{array}{c}0.0098 \\
(3.32)^{* *}\end{array}$ & $\begin{array}{c}0.0113 \\
(4.34)^{* *}\end{array}$ \\
\hline CPI & $\begin{array}{l}0.1390 \\
(0.59)\end{array}$ & $\begin{array}{l}-0.0980 \\
(-0.56)\end{array}$ & $\begin{array}{l}-0.5519 \\
(-2.45)^{*}\end{array}$ & $\begin{array}{l}-0.1830 \\
(-1.10)\end{array}$ & $\begin{array}{l}-0.0662 \\
(-0.40)\end{array}$ & $\begin{array}{l}0.0051 \\
(0.03)\end{array}$ \\
\hline FOREX & $\begin{array}{l}-0.0409 \\
(-2.32)^{*}\end{array}$ & $\begin{array}{l}-0.0092 \\
(-0.57)\end{array}$ & $\begin{array}{l}-0.0108 \\
(-0.74)\end{array}$ & $\begin{array}{l}-0.0300 \\
(-2.02)^{*}\end{array}$ & $\begin{array}{l}-0.0256 \\
(-1.62)\end{array}$ & $\begin{array}{l}-0.0303 \\
(-1.73)\end{array}$ \\
\hline OIL & $\begin{array}{c}0.0004 \\
(3.77)^{* *}\end{array}$ & $\begin{array}{c}0.0005 \\
(5.76)^{* *}\end{array}$ & $\begin{array}{c}0.0006 \\
(7.04)^{* *}\end{array}$ & $\begin{array}{c}0.0005 \\
(6.69)^{* *}\end{array}$ & $\begin{array}{c}0.0005 \\
(6.44)^{* *}\end{array}$ & $\begin{array}{c}0.0005 \\
(6.33)^{* *}\end{array}$ \\
\hline IPROD & $\begin{array}{c}-0.2773 \\
(-9.04)^{* *}\end{array}$ & $\begin{array}{c}-0.2479 \\
(-8.63)^{* *}\end{array}$ & $\begin{array}{c}-0.2127 \\
(-7.32)^{* *}\end{array}$ & $\begin{array}{c}-0.2550 \\
(-8.81)^{* *}\end{array}$ & $\begin{array}{c}-0.2646 \\
(-8.87)^{* *}\end{array}$ & $\begin{array}{c}-0.2584 \\
(-8.27)^{* *}\end{array}$ \\
\hline R-squared & 0.6961 & 0.5739 & 0.5312 & 0.5855 & 0.6020 & 0.6575 \\
\hline Hausman test & $3.35[0.76]$ & $2.56[0.77]$ & $1.81[0.87]$ & $2.82[0.73]$ & $2.49[0.78]$ & $9.29[0.10]$ \\
\hline LM test & $32.91[0.00]$ & $32.77[0.00]$ & $23.18[0.00]$ & $42.02[0.00]$ & $41.86[0.00]$ & $28.30[0.00]$ \\
\hline \multicolumn{7}{|c|}{ Panel B: Developed markets } \\
\hline $\mathrm{G} i$ & $\begin{array}{c}-0.0019 \\
(-1.87)\end{array}$ & $\begin{array}{c}0.0015 \\
(0.71)\end{array}$ & $\begin{array}{c}-0.0022 \\
(-1.54)\end{array}$ & $\begin{array}{c}-0.0040 \\
(-1.71)\end{array}$ & $\begin{array}{c}-0.0012 \\
(-0.61)\end{array}$ & $\begin{array}{c}-0.0007 \\
(-0.58)\end{array}$ \\
\hline$\beta^{\text {WORLD }}$ & $\begin{array}{c}0.0188 \\
(11.33)^{* *}\end{array}$ & $\begin{array}{c}0.0186 \\
(12.41)^{* *}\end{array}$ & $\begin{array}{c}0.0170 \\
(9.11)^{* *}\end{array}$ & $\begin{array}{c}0.0168 \\
(10.02)^{* *}\end{array}$ & $\begin{array}{c}0.0180 \\
(10.70)^{* *}\end{array}$ & $\begin{array}{c}0.0174 \\
(10.52)^{* *}\end{array}$ \\
\hline CPI & $\begin{array}{l}0.1950 \\
(2.38)^{*}\end{array}$ & $\begin{array}{c}-0.0507 \\
(-0.47)\end{array}$ & $\begin{array}{c}-0.6301 \\
(-6.09)^{* *}\end{array}$ & $\begin{array}{c}-0.4553 \\
(-4.26)^{* *}\end{array}$ & $\begin{array}{l}-0.2086 \\
(-2.13)^{*}\end{array}$ & $\begin{array}{c}-0.1302 \\
(-1.48)\end{array}$ \\
\hline FOREX & $\begin{array}{c}-0.0349 \\
(-5.56)^{* *}\end{array}$ & $\begin{array}{c}-0.0218 \\
(-2.57)^{* *}\end{array}$ & $\begin{array}{c}-0.0062 \\
(-1.00)\end{array}$ & $\begin{array}{c}-0.0194 \\
(-2.98)^{* *}\end{array}$ & $\begin{array}{c}-0.0193 \\
(-3.12)^{* *}\end{array}$ & $\begin{array}{c}-0.0196 \\
(-3.07)^{* *}\end{array}$ \\
\hline OIL & $\begin{array}{c}0.0004 \\
(11.44)^{* *}\end{array}$ & $\begin{array}{c}0.0005 \\
(13.67)^{* *}\end{array}$ & $\begin{array}{c}0.0006 \\
(20.53)^{* *}\end{array}$ & $\begin{array}{c}0.0006 \\
(16.95)^{* *}\end{array}$ & $\begin{array}{c}0.0005 \\
(17.24)^{* *}\end{array}$ & $\begin{array}{c}0.0005 \\
(16.84)^{* *}\end{array}$ \\
\hline IPROD & $\begin{array}{c}-0.2941 \\
(-20.55)^{* *}\end{array}$ & $\begin{array}{c}-0.2866 \\
(-17.38)^{* *}\end{array}$ & $\begin{array}{c}-0.2576 \\
(-15.23)^{* *}\end{array}$ & $\begin{array}{c}-0.2693 \\
(-17.02)^{* *}\end{array}$ & $\begin{array}{c}-0.2857 \\
(-18.83)^{* *}\end{array}$ & $\begin{array}{c}-0.2834 \\
(-18.40)^{* *}\end{array}$ \\
\hline R-squared & 0.8396 & 0.7915 & 0.7599 & 0.7677 & 0.7911 & 0.7848 \\
\hline Hausman test & $2.12[0.83]$ & $5.05[0.41]$ & $1.74[0.88]$ & $8.42[0.21]$ & $1.44[0.92]$ & $3.70[0.59]$ \\
\hline LM test & $20.54[0.00]$ & $22.74[0.00]$ & $29.14[0.00]$ & $35.23[0.00]$ & $24.56[0.00]$ & $29.02[0.00]$ \\
\hline
\end{tabular}

Notes: Dependent variable is total risk. Panel A and Panel B report the estimation results for emerging and developed markets respectively. Gi represents the six governance indicators as follows: G1 is Voice and Accountability; G2 is Political Stability and Absence of Violence; G3 is Government Effectiveness; G4 is Regulatory Quality; G5 is Rule of Law; and G6 is Control of Corruption. $\beta^{\text {WORLD }}$ is the world beta coefficient and it captures sensitivity of country $i$ 's equity return to world market movement. The variables CPI, FOREX, OIL, and IPROD are other global risk factors as represented by inflation rate, foreign exchange rate, crude oil spot price changes, and industrial production growth respectively. $t$-statistics are in parentheses and adjusted for heteroskedasticity in the error terms. $p$ values are in square brackets. ${ }^{* *}$ and $*$ denote statistical significance at the 1 and 5 percent levels respectively. 
This evidence is in sharp contrast to the findings reported for emerging market countries where all six governance dimensions play significant roles in explaining the crosscountry differences in equity market risk. While none of the governance indicators is significant, the R-squared values of 0.76 to 0.84 are consistently higher than those of the emerging markets. The extremely high significant coefficients of world beta, exchange rate, crude oil price and industrial production risk factors suggest that cross-country differences in equity market risk of developed markets are primarily induced by world market movement and global risk factors.

In Table 4, the dependent variable employed is semi-deviation of a country's MSCI returns. For emerging equity markets, the results are very similar to those obtained using the standard deviation of equity return. The quality of a country's governance framework is shown to have profound influence on its equity market risk even after controlling for the effects of world market movement and global risk factors. The results for developed markets in Panel B show that the two dimensions of a country's governance framework deemed particularly important in influencing equity market risk are Government Effectiveness (G3) and Regulatory Quality (G4). This suggests that semi-deviation of equity return is able to capture a country's risk exposure related to ineffective government and low regulatory quality.

In sum, the overall findings suggest that investors in emerging markets need to pay more attention to a country's governance framework than do investors in developed markets. Governance-related risk is considered an important risk exposure and thus can potentially serve as an additional risk factor in the pricing model of stock market in emerging markets countries.

\section{Conclusions}

This paper investigates the link between the quality of country-level governance and equity market risk in developed and emerging countries over the period from January 2002 to December 2009 employing balanced panel data regressions. The two equity market risk measures employed are standard deviation of equity return and semi-deviation of equity return. For emerging market countries, our findings indicate that country-level governance risks are important drivers of equity market risk. The quality of governance measured by Voice and Accountability, Political Stability and Absence of Violence, Government Effectiveness, Regulatory Quality, Rule of Law, and Control of Corruption are important drivers of stock market risk. Emerging market countries with lower scores on these governance dimensions have higher stock market risk than those with better governance scores. On the contrary, the results for developed equity markets show that none of the country-specific governance indicators is able to explain the cross-sectional differences in equity risk using standard deviation of equity return measure. However, when semi-deviation of equity return is employed as the risk measure, two governance dimensions, namely Government Effectiveness and Regulatory Quality are significant in explaining the cross-country differences in stock market risk of developed countries. 
Table 4. Panel regression of equity market risk on governance variables and global risk factors over the period January 2002 - December 2009

\begin{tabular}{|c|c|c|c|c|c|c|}
\hline & $(1)$ & $(2)$ & (3) & (4) & $(5)$ & ( 6 ) \\
\hline \multicolumn{7}{|c|}{ Panel A: Emerging markets } \\
\hline $\mathrm{G} i$ & $\begin{array}{c}-0.0037 \\
(-2.61)^{* *}\end{array}$ & $\begin{array}{l}-0.0021 \\
(-2.25)^{*}\end{array}$ & $\begin{array}{l}-0.0053 \\
(-4.25)^{* *}\end{array}$ & $\begin{array}{l}-0.0042 \\
(-2.66)^{* *}\end{array}$ & $\begin{array}{c}-0.0036 \\
(-3.07)^{* *}\end{array}$ & $\begin{array}{c}-0.0055 \\
(-3.61)^{* *}\end{array}$ \\
\hline$\beta^{\text {WORLD }}$ & $\begin{array}{c}0.0100 \\
(6.16)^{* *}\end{array}$ & $\begin{array}{c}0.0080 \\
(4.87)^{* *}\end{array}$ & $\begin{array}{c}0.0066 \\
(4.09)^{* *}\end{array}$ & $\begin{array}{c}0.0080 \\
(5.04)^{* *}\end{array}$ & $\begin{array}{c}0.0078 \\
(4.59)^{* *}\end{array}$ & $\begin{array}{c}0.0087 \\
(6.02)^{* *}\end{array}$ \\
\hline CPI & $\begin{array}{l}0.1778 \\
(1.34)\end{array}$ & $\begin{array}{c}-0.0220 \\
(-0.22)\end{array}$ & $\begin{array}{l}-0.3916 \\
(-2.78)^{* *}\end{array}$ & $\begin{array}{c}-0.0996 \\
(-0.97)\end{array}$ & $\begin{array}{c}-0.0188 \\
(-0.20)\end{array}$ & $\begin{array}{l}0.0273 \\
(0.30)\end{array}$ \\
\hline FOREX & $\begin{array}{l}-0.0253 \\
(-2.23)^{*}\end{array}$ & $\begin{array}{c}-0.0067 \\
(-0.61)\end{array}$ & $\begin{array}{c}-0.0064 \\
(-0.61)\end{array}$ & $\begin{array}{c}-0.0201 \\
(-1.89)\end{array}$ & $\begin{array}{c}-0.0169 \\
(-1.55)\end{array}$ & $\begin{array}{c}-0.0193 \\
(-1.71)\end{array}$ \\
\hline OIL & $\begin{array}{c}0.0002 \\
(4.76)^{* *}\end{array}$ & $\begin{array}{c}0.0003 \\
(7.45)^{* *}\end{array}$ & $\begin{array}{c}0.0004 \\
(9.27)^{* *}\end{array}$ & $\begin{array}{c}0.0003 \\
(8.89)^{* *}\end{array}$ & $\begin{array}{c}0.0003 \\
(8.92)^{* *}\end{array}$ & $\begin{array}{c}0.0003 \\
(9.22)^{* *}\end{array}$ \\
\hline IPROD & $\begin{array}{c}-0.1842 \\
(-12.13)^{* *}\end{array}$ & $\begin{array}{c}-0.1671 \\
(-11.19)^{* *}\end{array}$ & $\begin{array}{c}-0.1433 \\
(-8.86)^{* *}\end{array}$ & $\begin{array}{c}-0.1718 \\
(-11.08)^{* *}\end{array}$ & $\begin{array}{c}-0.1775 \\
(-11.62)^{* *}\end{array}$ & $\begin{array}{c}-0.1722 \\
(-11.21)^{* *}\end{array}$ \\
\hline R-squared & 0.7311 & 0.6164 & 0.5799 & 0.6198 & 0.6382 & 0.6987 \\
\hline Hausman test & $2.22[0.90]$ & $1.93[0.86]$ & $1.49[0.91]$ & $1.13[0.95]$ & $0.81[0.98]$ & $6.23[0.28]$ \\
\hline LM test & $48.50[0.00]$ & $45.11[0.00]$ & $30.88[0.00]$ & $55.52[0.00]$ & $58.53[0.00]$ & $41.60[0.00]$ \\
\hline \multicolumn{7}{|c|}{ Panel B: Developed markets } \\
\hline $\mathrm{G} i$ & $\begin{array}{c}-0.0006 \\
(-0.84)\end{array}$ & $\begin{array}{c}0.0009 \\
(0.58)\end{array}$ & $\begin{array}{l}-0.0022 \\
(-2.39)^{*}\end{array}$ & $\begin{array}{l}-0.0036 \\
(-2.43)^{*}\end{array}$ & $\begin{array}{c}-0.0009 \\
(-0.73)\end{array}$ & $\begin{array}{l}-0.0008 \\
(-1.07)\end{array}$ \\
\hline$\beta^{\text {WORLD }}$ & $\begin{array}{c}0.0137 \\
(11.99)^{* *}\end{array}$ & $\begin{array}{c}0.0136 \\
(12.41)^{* *}\end{array}$ & $\begin{array}{c}0.0124 \\
(9.33)^{* *}\end{array}$ & $\begin{array}{c}0.0123 \\
(10.13)^{* *}\end{array}$ & $\begin{array}{c}0.0133 \\
(11.02)^{* *}\end{array}$ & $\begin{array}{c}0.0128 \\
(10.43)^{* *}\end{array}$ \\
\hline CPI & $\begin{array}{c}0.2073 \\
(3.80)^{* *}\end{array}$ & $\begin{array}{l}0.0703 \\
(1.00)\end{array}$ & $\begin{array}{l}-0.3432 \\
(-4.81)^{* *}\end{array}$ & $\begin{array}{c}-0.2088 \\
(-3.06)^{* *}\end{array}$ & $\begin{array}{c}-0.0253 \\
(-0.43)\end{array}$ & $\begin{array}{l}-0.0011 \\
(-0.02)\end{array}$ \\
\hline FOREX & $\begin{array}{l}-0.0253 \\
(-4.53)^{* *}\end{array}$ & $\begin{array}{l}-0.0167 \\
(-2.43)^{*}\end{array}$ & $\begin{array}{c}-0.0043 \\
(-0.82)\end{array}$ & $\begin{array}{l}-0.0131 \\
(-2.49)^{*}\end{array}$ & $\begin{array}{l}-0.0133 \\
(-2.55)^{*}\end{array}$ & $\begin{array}{l}-0.0142 \\
(-2.57)^{* *}\end{array}$ \\
\hline OIL & $\begin{array}{c}0.0003 \\
(10.11)^{* *}\end{array}$ & $\begin{array}{c}0.0003 \\
(12.79)^{* *}\end{array}$ & $\begin{array}{c}0.0004 \\
(17.77)^{* *}\end{array}$ & $\begin{array}{c}0.0004 \\
(15.80)^{* *}\end{array}$ & $\begin{array}{c}0.0003 \\
(15.32)^{* *}\end{array}$ & $\begin{array}{c}0.0003 \\
(15.00)^{* *}\end{array}$ \\
\hline IPROD & $\begin{array}{c}-0.2140 \\
(-19.19)^{* *} \\
\end{array}$ & $\begin{array}{c}-0.2110 \\
(-16.69)^{* *}\end{array}$ & $\begin{array}{c}-0.1909 \\
(-14.68)^{* *} \\
\end{array}$ & $\begin{array}{c}-0.1995 \\
(-16.45)^{* *} \\
\end{array}$ & $\begin{array}{c}-0.2101 \\
(-17.97)^{* *}\end{array}$ & $\begin{array}{c}-0.2084 \\
(-17.87)^{* *}\end{array}$ \\
\hline R-squared & 0.8399 & 0.7942 & 0.7627 & 0.7690 & 0.7928 & 0.7895 \\
\hline Hausman test & $2.54[0.77]$ & $3.48[0.63]$ & $2.82[0.73]$ & $10.28[0.11]$ & $7.63[0.19]$ & $2.37[0.80]$ \\
\hline LM test & $21.15[0.00]$ & $21.51[0.00]$ & $26.60[0.00]$ & $29.62[0.00]$ & $22.23[0.00]$ & $23.54[0.00]$ \\
\hline
\end{tabular}

Notes: Dependent variable is downside risk. Panel A and Panel B report the estimation results for emerging and developed markets respectively. Gi represents the six governance indicators as follows: G1 is Voice and Accountability; G2 is Political Stability and Absence of Violence; G3 is Government Effectiveness; G4 is Regulatory Quality; G5 is Rule of Law; and G6 is Control of Corruption. $\beta^{\text {WORLD }}$ is the world beta coefficient and it captures sensitivity of country $i$ 's equity return to world market movement. The variables CPI, FOREX, OIL, and IPROD are other global risk factors as represented by inflation rate, foreign exchange rate, crude oil spot price changes, and industrial production growth respectively. $t$-statistics are in parentheses and adjusted for heteroskedasticity in the error terms. $p$ values are in square brackets. ${ }^{* *}$ and $*$ denote statistical significance at the 1 and 5 percent levels respectively. 
Overall, the findings for developed countries suggest that there is generally little or no relation between country-level governance quality and stock market risk. Insights from this study are useful in providing policy directions to address the broader governance agenda in emerging market countries and enhance the academic literature on the various governance-related factors that are important in driving stock market risk of emerging market countries.

\section{References}

Aggarwal, R.; Inclan, C.; Leal, R. 1999. Volatility in emerging stock markets, Journal of Financial and Quantitative Analysis 34(1): 33-55. http://dx.doi.org/10.2307/2676245

Beck, T.; Dermirguc-Kunt, A.; Levine, R. 2003. Law and finance: why does legal origin matter?, Journal of Comparative Economics 31(4): 653-657. http://dx.doi.org/10.1016/j.jce.2003.08.001

Berkowitz, D.; Pistor, K.; Richard, J.-F. 2003. Economic development, legality, and the transplant effect, European Economic Review 47(1): 165-195.

http://dx.doi.org/10.1016/S0014-2921(01)00196-9

Bialkowski, J. P.; Gottschalk, K.; Wisniewski, T. P. 2008. Stock market volatility around national elections, Journal of Banking and Finance 32(9): 1941-1953.

http://dx.doi.org/10.1016/j.jbankfin.2007.12.021

Charles, A.; Darne, O. 2014. Large shocks in the volatility of the Dow Jones Industrial Average index: 1928-2013, Journal of Banking and Finance 43(C): 188-199. http://dx.doi.org/10.1016/j.jbankfin.2014.03.022

Chau, F.; Deesomsak, R.; Wang, J. 2014. Political uncertainty and stock market volatility in the Middle East and North African (MENA) countries, Journal of International Financial Markets, Institutions and Money 28(C): 1-19. http://dx.doi.org/10.1016/j.intfin.2013.10.008

Chen, K. C. W.; Chen, Z.; Wei, K. C. J. 2009. Legal protection of investors, corporate governance, and the cost of equity capital, Journal of Corporate Finance 15(3): 273-289.

http://dx.doi.org/10.1016/j.jcorpfin.2009.01.001

Chiou, W.-J .P.; Lee, A. C.; Lee, C.-F. 2010. Stock return, risk, and legal environment around the world, International Review of Economics and Finance 19(1): 95-105.

http://dx.doi.org/10.1016/j.iref.2009.05.001

Claessens, S.; Djankov, S.; Larry, L. 2000. The separation of ownership and control in East Asian corporations, Journal of Financial Economics 58(1-2): 81-112.

http://dx.doi.org/10.1016/S0304-405X(00)00067-2

Daouk, H.; Lee, C. M. C.; Ng, D. 2006. Capital market governance: how do security laws affect market performance?, Journal of Corporate Finance 12(3): 560-593.

http://dx.doi.org/10.1016/j.jcorpfin.2005.03.003

Dumas, B.; Solnik, B. 1995. The world price of foreign exchange risk, Journal of Finance 50(2): 445-479. http://dx.doi.org/10.1111/j.1540-6261.1995.tb04791.x

Dumludag, D. 2009. An analysis of the determinants of foreign direct investment in Turkey: the role of the institutional context, Journal of Business Economics and Management 10(1): 15-30. http://dx.doi.org/10.3846/1611-1699.2009.10.15-30

Eldor, R.; Melnick, R. 2004. Financial markets and terrorism, European Journal of Political Economy 20(2): 367-386. http://dx.doi.org/10.1016/j.ejpoleco.2004.03.002

Estrada, J. 2007. Mean-semivariance behavior: downside risk and capital asset pricing, International Review of Economics and Finance 16(2): 169-185.

http://dx.doi.org/10.1016/j.iref.2005.03.003 
Ferson, W. E.; Harvey, C. R. 1993. The risk and predictability of international equity returns, Review of Financial Studies 6(3): 527-566. http://dx.doi.org/10.1093/rfs/6.3.527

Franck, R.; Krausz, M. 2009. Institutional changes, wars and stock market risk in an emerging economy: evidence from the Israeli stock exchange, 1945-1960, Cliometrica 3(2): 141-164. http://dx.doi.org/10.1007/s11698-008-0030-z

Giannetti, M.; Koskinen, Y. 2010. Investor protection, equity returns, and financial globalization, Journal of Financial and Quantitative Analysis 45(1): 135-168.

http://dx.doi.org/10.1017/S0022109009990524

Gompers, P. A.; Ishii, J. L.; Metrick, A. 2003. Corporate governance and equity prices, Quarterly Journal of Economics 118(1): 107-155. http://dx.doi.org/10.1162/00335530360535162

Hail, L.; Leuz, C. 2006. International differences in the cost of equity capital: do legal institutions and securities regulation matter?, Journal of Accounting Research 44(3): 485-531.

http://dx.doi.org/10.1111/j.1475-679X.2006.00209.x

Harvey, C. R. 1995. Predictable risk and returns in emerging markets, Review of Financial Studies 8(3): 773-816. http://dx.doi.org/10.1093/rfs/8.3.773

Hooper, V.; Sim, A. B.; Uppal, A. 2009. Governance and stock market performance, Journal of Economic Systems 33(2): 93-116. http://dx.doi.org/10.1016/j.ecosys.2009.03.001

Kaufmann, D.; Kraay, A.; Mastruzzi, M. 2010. The worldwide governance indicators: methodology and analytical issues, World Bank Policy Research Working Paper 5430.

Kim, H. Y.; Mei, J. P. 2001. What makes the stock market jump? An analysis of political risk on Hong Kong stock returns, Journal of International Money and Finance 20(7): 1003-1016. http://dx.doi.org/10.1016/S0261-5606(01)00035-3

Klapper, L. F.; Love, I. 2004. Corporate governance, investor protection, and performance in emerging markets, Journal of Corporate Finance 10(5): 703-728.

http://dx.doi.org/10.1016/S0929-1199(03)00046-4

La Porta, R.; Lopez-de-Silanes, F.; Shleifer, A.; Vishny, R. 1997. Legal determinants of external finance, Journal of Finance 52(3): 1131-1150.

http://dx.doi.org/10.1111/j.1540-6261.1997.tb02727.x

La Porta, R.; Lopez-de-Silanes, F.; Shleifer, A.; Vishny, R. 1998. Law and finance, Journal of Political Economy 106(6): 1113-1155. http://dx.doi.org/10.1086/250042

Lombardo, D.; Pagano, M. 2006. Legal determinants of the return on equity, in L. Oxelheim (Ed.). Corporate and institutional transparency for economic growth in Europe. Oxford: Elsevier.

Low, S.-W.; Kew, S.-R.; Tee, L.-T. 2011. International evidence on the link between quality of governance and stock market performance, Global Economic Review 40(3): 361-384.

http://dx.doi.org/10.1080/1226508X.2011.601646

Mateus, T. 2004. The risk and predictability of equity returns of the EU accession countries, Emerging Markets Review 5(2): 241-266. http://dx.doi.org/10.1016/j.ememar.2004.03.003

World Bank's Worldwide Governance Indicators (WGI). 2011. [Online], [cited 4 May 2011]. Available from Internet: www.govindicators.org

Yartey, C. A. 2010. The institutional and macroeconomic determinants of stock market development in emerging economies, Applied Financial Economics 20(21): 1615-1625.

http://dx.doi.org/10.1080/09603107.2010.522519 


\section{APPENDIX A}

\section{Definitions of six dimensions of governance indicators}

1. Voice and Accountability - capturing perceptions of the extent to which a country's citizens are able to participate in selecting their government, as well as freedom of expression, freedom of association, and a free media.

2. Political Stability and Absence of Violence - capturing perceptions of the likelihood that the government will be destabilized or overthrown by unconstitutional or violent means, including politically-motivated violence and terrorism.

3. Government Effectiveness - capturing perceptions of the quality of public services, the quality of the civil service and the degree of its independence from political pressures, the quality of policy formulation and implementation, and the credibility of the government's commitment to such policies.

4. Regulatory Quality - capturing perceptions of the ability of the government to formulate and implement sound policies and regulations that permit and promote private sector development.

5. Rule of Law - capturing perceptions of the extent to which agents have confidence in and abide by the rules of society, and in particular the quality of contract enforcement, property rights, the police, and the courts, as well as the likelihood of crime and violence.

6. Control of Corruption - capturing perceptions of the extent to which public power is exercised for private gain, including both petty and grand forms of corruption, as well as "capture" of the state by elites and private interests.

Adapted from Kaufmann et al. (2010: 4).

\section{APPENDIX B}

\section{Correlation coefficients}

\begin{tabular}{|c|c|c|c|c|c|c|}
\hline & G1 & $\mathrm{G} 2$ & G3 & G4 & G5 & G6 \\
\hline \multicolumn{7}{|c|}{ Panel A: Emerging markets } \\
\hline G1 & 1 & & & & & \\
\hline G2 & $0.614 * *$ & 1 & & & & \\
\hline G3 & $0.651^{* *}$ & $0.804^{* *}$ & 1 & & & \\
\hline G4 & $0.787 * *$ & $0.788^{* *}$ & $0.880 * *$ & 1 & & \\
\hline G5 & $0.661 * *$ & $0.833 * *$ & $0.898 * *$ & $0.836^{* *}$ & 1 & \\
\hline G6 & $0.737 * *$ & $0.783 * *$ & $0.890 * *$ & $0.925 * *$ & $0.883 * *$ & 1 \\
\hline \multicolumn{7}{|c|}{ Panel B: Developed markets } \\
\hline G1 & 1 & & & & & \\
\hline $\mathrm{G} 2$ & $0.336^{* *}$ & 1 & & & & \\
\hline G3 & $0.256^{* *}$ & $0.558 * *$ & 1 & & & \\
\hline G4 & 0.091 & $0.507 * *$ & $0.797 * *$ & 1 & & \\
\hline G5 & $0.421 * *$ & $0.622 * *$ & $0.883 * *$ & $0.792 * *$ & 1 & \\
\hline G6 & $0.273 * *$ & $0.572 * *$ & $0.915 * *$ & $0.850 * *$ & $0.933 * *$ & 1 \\
\hline
\end{tabular}


Correlation coefficients of country-level governance variables for emerging and developed markets are reported. G1: Voice and Accountability; G2: Political Stability and Absence of Violence; G3: Government Effectiveness; G4: Regulatory Quality; G5: Rule of Law; and G6: Control of Corruption. ** and * imply statistical significance at the 1 percent and 5 percent levels respectively.

Soo-Wah LOW is a Professor of Finance at the UKM-Graduate School of Business, Universiti Kebangsaan Malaysia. She received her Bachelor of Business Administration from Universiti Kebangsaan Malaysia, her MBA and Ph.D. from University of Arkansas, Fayetteville, USA. She has published in among others, the Journal of Banking and Finance, Applied Economics, Emerging Markets Review, and Global Economic Review. Her current research interests include unit trust/mutual funds, IPOs, financial development (stock market/banking) and issues related to Asian financial markets.

Lain-Tze TEE is a Lecturer of Finance at the School of Management, Faculty Economics and Management, Universiti Kebangsaan Malaysia. His academic credentials include a BBA degree in Finance from Universiti Kebangsaan Malaysia, where he also earned his MBA in Applied Finance and Investment. His recent work has been published in Global Economic Review. His primary research interests are in asset pricing, country-level governance, financial development, and emerging financial markets.

Si-Roei KEW is a Lecturer of Finance at the School of Management, Faculty Economics and Management, Universiti Kebangsaan Malaysia. She earned her master and undergraduate degrees in Finance from Universiti Kebangsaan Malaysia. Her recent research work has been published in Global Economic Review. Her research interests are in the areas of stock market efficiency, Asian capital markets and knowledge-based economy. 